\title{
Ordinary, Adequate, and Crazy: Reconsidering the "Pyramid" Metaphor for Mass-participation Sports
}

\author{
Andrey S. Adelfinsky \\ Candidate of Economic Sciences, Associate Professor, Bauman Moscow State Technical University \\ Address: Baumanskaya 2-ya str., 5, Moscow, Russian Federation 105005 \\ E-mail: adelfi@mail.ru
}

\begin{abstract}
The article critically examines the "pyramid" metaphor for mass-participation sports. It focuses on the heterogeneity of intra-group structure and motives among adult amateurs participating in open races in running, triathlon, etc. The study is based on comparative participant observation at Russian and European mass-sports events and semi-formalized interviews. We describe the lifestyle and motives of non-elite athletes. Mostly they participate "for fit, for fun, for challenge, for socialization", defined as key motives. Participation in races is essential for healthy lifestyle. However, the motive "for health" is peripheral. We noted a latent motive of "to win, to be ahead of others". It reflects the very nature of sports, but creates a "loser's problem" subverting participation. We show how skill-level and a balance between key and latent motives constitute three strata among non-elite athletes. We define these strata as "Ordinary", "Adequate" and "Crazy" and demonstrate how the motivation difference produces hidden controversies among them. Our theoretical interpretation is based on Norbert Elias's concept of civilizing process and Konrad Lorenz's comparative anthropology. We outline two normative sports models. For the Expressive model, the key motives "fit, fun, challenge, socialization" are socially approved, but for the Traditional-competitive or Top-achievements model, only the latent motive of "to win" looks legitimate. We believe that mass-participation sports emerged due to modern recognition of the Expressive model as a new social norm, while the Competitive model hinders its development. Rejecting the "pyramid" metaphor in sports, we propose an "iceberg" metaphor wherein these models coexist through different social roles.
\end{abstract}

Keywords: mass-participation sports, running, triathlon, cycling, sports for all, sports pyramid, civilizing process, social norms, sociology of sports, trickle-down effect, elite sport

\section{Why do They Run?}

The past decade was marked by a new wave of a fitness-boom, the second of the last half-century. In the 2010s, this second wave became particularly intense in Russia. Many adults who were far away from sports in the recent past suddenly found a passion for participating in mass-events such as distance running, triathlon, road cycling, Nordic skiing, open-water swimming, etc. Watching these massive races, the present-day observer has the right to ask the same questions as Hunter S. Thompson did in the 1980s: "Why do these buggers run? What kind of sick instinct, stroked by countless hours of brutal training, would cause intelligent people to get up at 4 in the morning and stagger through the 
streets for 26 ball-busting miles in a race that less than a dozen of them have any chance of winning?" (1983).

A number of studies done in the West have already answered the question of the social structure of mass-participation sports, and about the motives of adults to engage in these activities. Quantitative, qualitative, and ethnographic methods were used. However, the number of such works in Russia is extremely small; they mostly refer to the first wave of the fitness boom of the 1980s. Thus, for Russian scholarly discourse, our research, including its early versions $(2013,2018$ : Ch. 4), is perhaps the first contemporary attempt to ask these questions. Another feature of the work is its cross-cultural character. Empirical data, i.e., observations and interviews, were collected at both Russian and European mass-events. In theoretical terms, the paper contributes to the critical debates around the sports "pyramid" metaphor. Originally attributed to Coubertin, this metaphor is still an influential concept that normatively describes the social order in modern sports. Thus, the purpose of this paper is to reconsider the "pyramid" metaphor for mass-participation sports through the study of intra-group structure and the motives of non-elite competitors. We propose a new vision, mostly inspired by the Leicester school of sports sociology and the evolutionary anthropology approach.

This paper is structured as follows. A critical controversy about the sports "pyramid" metaphor is presented at the beginning. Next, we clarify the explored phenomenon of mass-competitions. It is followed by the review of literature on intra-group structure and participation motives among adult non-elite amateurs. Then, in accordance with this internal logic, we present our own results divided into two parts, voiced and latent. In the final discussion, we return to the critical debate on the "pyramid" metaphor and on the choosing of a relevant model for grassroots sports.

\section{Critical Discourse on the Sports Pyramid}

The "pyramid" metaphor represents the general organization of sports as a hierarchical system, where competitions and athletes are ranked by skill level, and where only the best, the so-called elite, are at the top. In the same time, mass- or grassroots-sports are seen as a "pyramid" foundation for which elite sports supposedly perform an "inspiring" function. This view is deeply rooted in sports politics. For instance, the Russian President Dmitry Medvedev stated that "The development of top-performance sports automatically leads to the progress of physical fitness, merely to the fact that people become healthier" (2008). It seems that his statement is based on Pierre de Coubertin long-standing "pyramid" thesis of "For one hundred to be engaged in physical culture, fifty must be engaged in sport. For fifty to do sport, twenty must specialize. For twenty to specialize, five must be capable of amazing feats" $(1913)^{1}$.

1. The original in French: "Pour que cent se livrent à la culture physique, il faut que cinquante fassent du sport. Pour que cinquante fas-sent du sport, il faut que vingt se spécialisent. Pour que vingt se spécialisent, il faut que cinq soient capables de prouesses éton-nantes". 
The Pyramid of Sport

(Kirkeby, 2007)

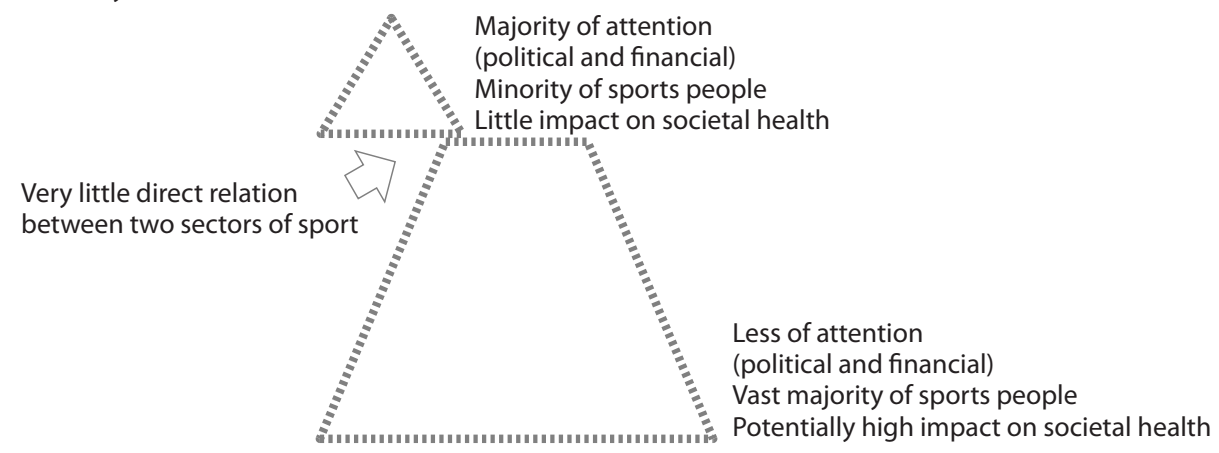

A new round of discussions concerning the sports pyramid metaphor has arisen in the context of the London 2012 Olympics. The contribution to stimulating grassroots sports participation was declared to be part of its future legacy. However, a number of studies do not prove the case (De Bosscher, Sotiriadou, Van Bottenburg, 2013; Weed et al., 2015; Seguí-Urbaneja et al., 2020). The thesis of the elite's "inspiring" function has been ironically defined as an "evangelical myth" (Grix, Carmichael, 2012). The metaphor of the "pyramid's displaced top" has been proposed, which demonstrates the gap between the top and the bottom in terms of funding, motivation, and the content of sports practices (Andreff, Dutoya, Montel, 2009; Kirkeby, 2009). The debate has a long and still ongoing history (Gleyse et al., 2001; Payne et al., 2003; De Cocq et al., 2018; De Rycke et al., 2021; Castellanos-García et al., 2021; etc.).

Critical understanding of this issue is almost absent from contemporary Russian authors, with a few exceptions. (Adelfinsky, 2013, 2020; Stolyarov, 2019). What is being studied are mainly factors and barriers to a so-called healthy lifestyle. (Zybunovskaya, Podkida, 2011; Roshchina, Gremchenko, 2016; Zasimova, Loktev, 2016; Makshanchikov, 2020 , etc.). Meanwhile, works of the 1980s-200os are quite complementary to the foreign discussion. The contradictions between segments of the "sport pyramid" were actively discussed as a part of the general debate of the problems of the Russian sports industry. These contradictions had already emerged in the Soviet period. As a result of the "Olympic U-turn" of sports policy in the USSR during the 1940s-1960s, more and more resources (financial, infrastructural, and human) were increasingly concentrating in the elite segment to the detriment of grassroots sporting activities.

The antagonistic relationship between these segments of the "sport pyramid" has been described by a number of experts and researchers, such as Petr Vinogradov, Alexander Vlasov, Yuri Vlasov, Anatoly Isaev, Lev Matveev, Oleg Milstein, and others (Adelfinsky, 2018: Ch. 1). They noted the discrepancy between the goal declared by the Soviet sport industry ("to develop a healthy lifestyle") and its actual tasks. By the early 1980s, grassroots sports were seen only as a supplier of human resources for "top achievements." 
According to Vlasov, "the physical education at school does not produce any effect", and the system of sports organization is such that "everything, the formation of sports sections even in the smallest cities, is brought to the solution of the main task: top achievements, gold medals" (1989). The motivation system of grassroots sports has been reduced to "top-achievements mania" in the spirit of the slogan "From the "Fit for Labor and Defense' badge to an Olympic medal". Matveev considered this approach as demagogic, anti-human, and deceptive (1999). There were objections to the normative goal-setting and even to the basic parts of the Sports industry abbreviation (in Russian it is designated as Physical Culture and Sports, abbreviated as FKiS). Within the framework of critical interpretations, physical culture was understood not as an individual activity, but as a collective effort of the whole of society. In terms of governance, it was proposed to divide sports into two segments, those of the Elite (highest achievements, professional, the "big sport"), and Mass (sport for all, grassroots, ordinary, or omnibus) ones. Accordingly, following Klaus Heinemann, we can talk of two sport models (in the sense of motives for participation), those of Traditional-competitive or Top-achievements (where the motive is to win, to defeat an opponent, to set a record, with a tendency to "Lombardian ethic" etc.), and Expressive (where the motive is a pleasure of the process itself). Thus, our paper continues the discussion on the "pyramid" division with a focus on individual motives for participation.

\section{Clarifying the Object}

The notion of sport in our paper is quite concrete. This is the phenomenon of open competitions in distance running, triathlon, road and cross-country cycling, xc-skiing, open water swimming, and similar sports disciplines. Typical examples of mass-events are running marathons (Berlin, Paris, London, Moscow, etc.), international triathlons (the ITU series, Challenge, Ironman, etc.), xc-ski marathons (the WorldLoppet series), etc. According to the official results, such races are attended by participants from 16 to 85 years of age and older. The distribution of athletes by age is similar to a bell-shaped curve, where the peak is around 40 years, the most numerous groups are $35-39$ and $40-44$ years, and about $2 / 3$ of the total athletes are from 30 to 49 years. The distribution by finish-times reveals a heterogeneous skill level. Participants include both elite athletes and people of very modest abilities. For example, in running marathons, the highest finish density is observed approximately in 4 hours, the last runners finish within 6 hours, practically walking, while elite athletes set the time of about 2 hours.

The described phenomenon of mass-participation races obviously does not fit into the stereotypical schemes of the "hierarchical sport pyramid" and "physical fitness for health' sake". Firstly, these races are open to the participation of everyone, without selection by skill and age. Most of the competing athletes are ordinary non-elite amateurs, and people of middle age and average physical abilities. Their participation in mass-competitions is a form of leisure, not a profession or its prospect. Races of the fastest elite athletes are not an end in themselves or a separate event. They are integrated into major events only 
as a part of the event. As we have demonstrated by an example of the ITU international triathlon circuit, the "pyramid" of elite races turned out to be only a very small surface part of an "iceberg" of mass participation (Adelfinsky, 2013).
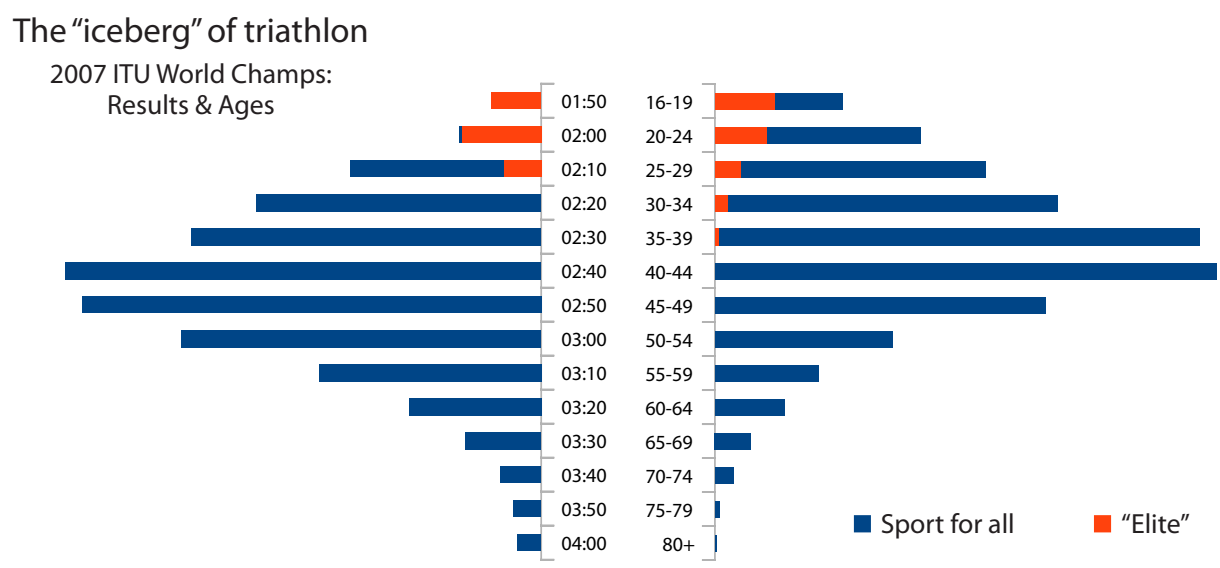

Secondly, it is difficult to consider participation in such competitions as "physical fitness for health' sake". Doctors do not recommend to sign up for multi-day cycling races, mountain trails, ski marathons, to swim across the Dnieper or the Bosphorus, or to run $42.195 \mathrm{~km}$ and warm up before this with a 180-kilometer bike ride. However, according to official results, regular participation in such events is precisely the leisure time of a modern 40-year-old "fitness enthusiast". Moreover, participants in such races are in fact people with a healthy lifestyle, since the very ability to complete the long distance is a fitness test. The importance of sports competitions for mass health is very well known (Semashko, 1927; Manzhosov, 1986; Uglov, 2001). At the same time, this raises the question of personal motives to participate in these mass-events.

\section{"Suffer — and Nothing Else!"}

The social structure's heterogeneity and the divergence of participation motives were already noted in early essays on mass-races. As Thompson wrote on the Honolulu running event, there are "two distinct groups here, two entirely different marathons." He discerned between the Racers (elite) and the rest of the Runners (1981). Our review of papers on lifestyles and motivations for mass-sport participation is based on works of the Leicester school of sociology. Its founders, Norbert Elias and Eric Dunning, considered sport in the general context of the civilizing process. Modern sport was understood as a tool of the "quest for excitement" and the release of spontaneous emotional affects (biological by nature). Moreover, it was a tool highly significant in the conditions of permanent self-control and cultural limitations characteristic for modern societies (1986). This interpretation is very close to the views of ethology in the spirit of Konrad Lorenz. For 
instance, some interpretations define his social reflection as comparative anthropology (Andryushina, 2016). This approach is also supported by biologists (see Zhukov, 2013), but if ethologists emphasize biological foundations of social behavior, Elias focuses on their cultural modification. He emphasized the diversity of accepted norms of decency in different eras, societies, and social groups.

The distance-running phenomenon has been studied by the Leicester School sociologist Stuart L. Smith. According to his works, the core of the practice is not those people who run for health or for charity, and definitely not those who start for prizes, victories, and "fast seconds". Smith identified three groups, those of the Athletes, Runners, and Joggers. The Athletes refer to a very small group of sportsmen who have the potential to win a race, or at least to perform well (i.e., the Elite). Joggers are another minor group, but they really run for health, physical fitness, etc. These two groups are considered to be peripheral for the practice of running. The core of the practice is Runners. They constitute the majority of participants at the races, although having no real chance of winning. However, their training and passion for running is clearly stronger than recommended for good fitness. In fact, "Exercise for health does not require running over 40 miles a week and competing over thirteen at the weekend", Smith notes (1998). For runners, there may be some element of competition with familiar faces (those they regularly meet at local races) and the idea of "their own best time". However, these points are not decisive. Smith writes about "a question of 'surviving' the distance" as a shared value in the running community. In his opinion, contemporary distance running is a form of selfrespect for middle-class men on the "wrong side of thirty". Smith emphasizes that most runners feel what they perceive to be respect and admiration from those not involved in the practice. The reason for this is that endurance running is a demonstration of physical qualities traditionally associated with masculinity (2000). Compared to non-runners, the runners "can continue to 'win' simply through continued participation. They need not even be particularly good at it" (1998). Another figurational sociologist described Canadian triathletes in the way very similar to British runners. They are a group of likeminded people whose core values are physical and emotional effort and the pleasure of overcoming (Atkinson, 2008).

Similar formulations are also found in the works of researchers associated with other schools. The main motivation for American cross-country triathletes was the opportunity to test their strength in competition with nature, themselves, and other people. Pleasure, enjoyment, and passion are indicated as key values (Case, Branch, 2001). For participants of the Canadian multi-day cycling marathon, the most significant motives were the challenging format, the opportunity to have fun, the thrilling experiences; the slightly-less significant motives were to improve athletic abilities, to take part in a journey and in something unusual, to communicate with like-minded people, and the least important motives were to win prizes, or to contribute to charity (Getz, McConnell, 2011). There are lot of new studies of runners and triathletes, but their general idea is the same (Lamont, Kennelly, 2012; Kruger et al., 2014; Poczta, Malchrowicz-Mośko, 2020; Ogles, Masters, 2003; Shipway et al., 2013; Hindley, 2020; etc.). For instance, Van Bottenberg et al. argue 
that modern runners participate to "complete" rather than "compete," seeing sport as a challenge rather than a victory (2010). This correlates with Smith's concept.

The similar emphasis on the challenge and extreme excitement is contained in the essays of Russian authors describing their participatory experience. For example, sports journalist Andrey Kondrashov talks about his first short triathlon: "It was not easy to decide on the first participation ... I was stopped by some fear of overcoming a new, unknown frontier." This author is one of pioneers of the Soviet triathlon; in those years, he was a 24-year-old scientist, and was a sub-elite xc-skier in his early youth. His story is about the early 1980s, when this sport was a novelty even for Western Europeans. He wrote that "The whole run can be summed up briefly: 'Suffer, and nothing else!' You move as if on autopilot. You ask yourself: 'What's the point of this nightmarish self-torture?' But your mind just cannot be strained to respond. However, there is no more delightful moment in a triathlon than the heavenly minutes after the finish line." In general, he describes his experience as exciting and unique: "Whoever wants to come across the moment of highest bliss, must 'do' a triathlon!” at least once (1995). Another author, topmanager Anatoly Shakhmatov, in those years a 42-year-old sports functionary who was a sub-elite swimmer in his youth, having had resumed training after a period of inactivity and alcohol addiction, said "Having learned about triathlon, ... from the very beginning I started thinking about the Iron distance. I was attracted by this formula for its seeming inaccessibility, just as a climber is attracted to new mountain peaks." He describes his impressions of the conquest as "Being somewhere in the middle of the running distance, I began to abstract myself, forgetting who am I, where and why was I rushing? ... After the finish, lying on the gym floor (everyone was lying!), for the first 15-20 minutes the body rejected any attempts to think and move... Then it was already possible to rise up, sit down and even make eyes at young girls ... with the feeling of being 'iron"' (1993).

These authors' results are generally very similar, but they also outline a certain general type of the ordinary amateur. The Japanese writer Haruki Murakami looks like he is probably the typical representative. At the age of 33, he quit smoking and started running. Subsequently, he published a collection of essays about his passion for distance running and triathlons. Murakami completed over 20 marathons with the best result of "three hours twenty-something minutes." This time is above-average, but with no chance to win, even in his age group. The feeling is of "surviving the distance" which he formulates as follows: "Say you're running and you start to think 'Man this hurts, I can't take it anymore. The hurt part is an unavoidable reality, but whether or not you can stand any more is up to the runner himself. This pretty much sums up the most important aspect of marathon running" (2008).

These citations allow us to construct the second ideal type as opposed to an elite athlete with his desire to win. This new type is an ordinary athlete with his "victory through participation only" and "a question of surviving". However, the question arises. Are these ideal motives really shared by all non-elite athletes? In particular, Smith mentions the narrow layer of "masters" or "veterans", emphasizing that none of them appeared in his sample. Our field observations reveal this question more fully. 
The gap between

Athletes \& Runners

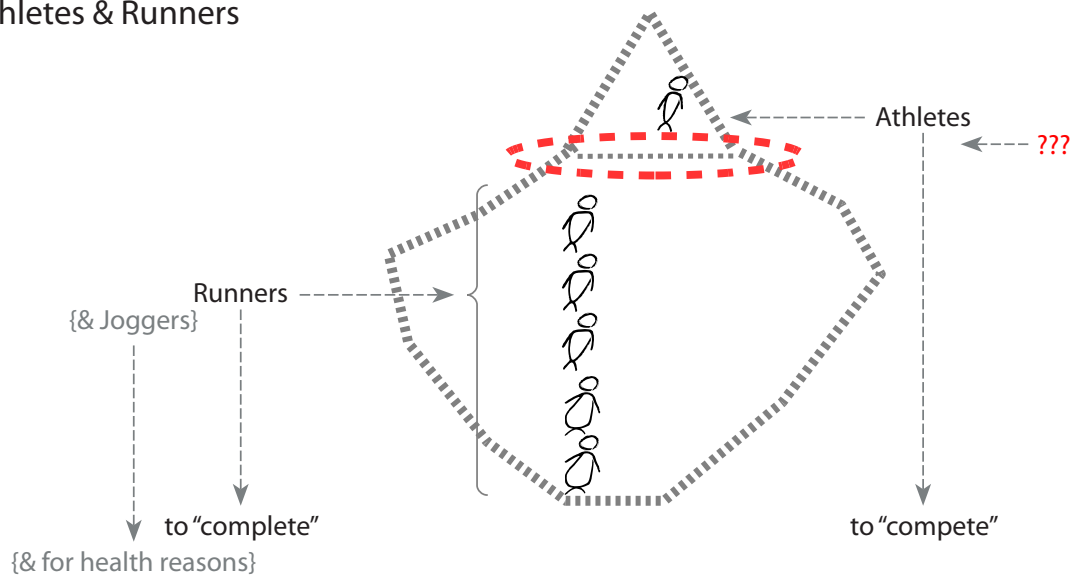

\section{Research Design and Methods}

Our research of inner-structure and motives in grassroots sports is based on qualitative methods. First of all, this is a long-term participant observation as a non-elite athlete in cyclic kinds of sports. These are mostly distance running and the triathlon, sometimes cross-country and road cycling, swimming, etc. The feature of our observation is that its objects were athletes participating in both domestic and foreign mass-races. The Russian block of observations was collected mainly in 2003-2012, before the second wave of fitness boom. During this period, the author, being an avid sports promoter, contributed to the revival of the non-elite triathlon in Russia. This process provided him with countless personal communications - in total, over two hundred - with adult amateurs in various related sports, and gave him rich observation material. The Western Block is based on unstructured interviews with participants of European open massive races, collected in 2007-2019. We interviewed non-elite amateur athletes 30-49 years of age, with over 3 years of racing experience, and involved in a number of cyclic activities (which is typical for triathletes). They were English-speaking Western Europeans, participants in international triathlons of standard and long distances, the multi-stage road cycling Tour TransAlp, and some local running races in the cities of Alanya, Augsburg, Geneva, Klagenfurt, Otepaa, Tartu, Roth, Nice, etc. The free interview contained two main questions asked during "equal to equal" dialogs, usually at pre- and post-race parties. The first one was "Why do you participate?", and the second, asked in a free form, with a request to clarify the motivation of "the desire to win, to defeat the opponent, to achieve high results." There are more than 50 such short interviews. Quotes from Western non-elite athletes are marked with $\{\mathrm{wA}\}$. Quotes of Russian non-elite amateurs and "veterans" are marked with $\{\mathrm{sA}\}$. For Russian sports subcultures other than distance running and the triathlon, disciplines are indicated directly: athletics, water-polo, soccer, swimming, Nordic skiing, 
and cross country and road cycling. Now, let's move on to presenting our results, starting with generalized answers to the first question: "Why do you participate?"

\section{The Voiced Motivation: Fit, Fun, Challenge, Socialization}

"For the challenge" was the most frequent response given by respondents at long distances. In endurance races, distance itself is a particular challenge. Reaching the finish line at multi-day cycling races, ultramarathons, or long triathlons are difficult tasks by itself. It takes 10-14 hours to overcome the iron-distance triathlon. A multi-day cycling race means 5-7 hours daily riding for a whole week. A classic running marathon takes only 3-5 hours, but its last quarter is not as comfortable as the previous ones. A response from $\{a W\}$ was "It's a heavy thing on its own. Anyone can try it for himself and check it." Most of respondents describe their motives for participating in iron distance triathlons and multi-day races in similar formulations. Again, from another $\{\mathrm{aW}\}$ : "When I found out for the first time, I didn't believe it. I decided to try, and started with a smaller format."

"For fun" is an often-heard answer. We can describe this "fun" in more detail. A couple of hours earlier, the respondent barely runs the distance. His face is twisted in a grimace of pain, from his lips flies: "Fuck", "Damn", "Oh my God", "No more", etc. When asked to associate the answer "fun" with his external appearance at the race, he explains the meaning of what was said by $\{\mathrm{aW}\}$ : "At first you work hard, then you endure it, by the end it's very hard. But after the finish there is a feeling of joy." Competitions are viewed as an opportunity to feel the thrill of races, to experience extreme excitement, to build a frame of reference. Comments range from $\{\mathrm{aW}\}$ 's: "Someone breathes on your back from behind, someone's back looms in front - an important stimulus."; $\{$ wA $\}$ : "You can never do it yourself."; $\{\mathrm{wA}\}$ : "Large crowd, feeling of excitement."; $\{\mathrm{wA}\}$ : "It's boring without events, there are no vivid emotions."; $\{\mathrm{wA}\}$ : "Just run is pointless, need some coordinates."; and $\{w A\}:$ " $10 \mathrm{~km}$ race is like a cup of a good wine. Life becomes easier." At the same time, competition, as it is, requires intense physical efforts at the maximum of the athlete's capacity, that is, good sportsmanship. The athlete acts as his own body controller; $\{\mathrm{wA}\}$ says "If you do not balk, you're acting unsportsmanlike., and $\{\mathrm{wA}\}$ : "You're kidding yourself."

"For socialization", etc., this common answer highlights another significant aspect of mass-participation sports events. That is the situation of "shared experience", and of the emergence and maintenance of new social ties. This is possible both through regular participation within the system of geographically localized events, but also when traveling outside.

"For fit" is understood and revealed in the general context of dialogs not as an abstraction, but as a compliance with a certain internal scale and is associated with the time result. There is an idea of "one's best time", to which non-elite sportsmen refer when discussing race goals or results, including "To pass steadily in speed", "Not to drop to walking", “To run K kilometers out of M minutes". However, these criteria are purely individual. 
"For health" was voiced on rare occasions as the main motive. It is important to emphasize that due to further conversation or observations, this answer could be interpreted differently. One $\{\mathrm{wA}\}$ stated that "After the end of my sports career I stopped practicing. Then I came across serious health problems. The doctor prescribed regular physical activity, at least an hour a day. I had to get involved again." The same respondent at the same time finds himself in a different situation. An accidental error in race results; as a consequence, he is not awarded by a podium place. He starts actively defending his right to win, demands a correction of the mistake, a new award ceremony. His reaction testifies to the importance of other motives. Another respondent $\{\mathrm{wA}\}$ said that "Due to inactivity, I had a pinched nerve, until blackout. I was scared, I started physical activity." At the same time, he participates in competitions, because for him, "It makes some sense; it motivates you, you start preparing, some kind of plan arises." After the race, he talks about the contest in detail with his occasional rivals at a distance, although he finishes in the tail-end of the official results.

The above motives were voiced in similar formulations, in different combinations, and enumeration orders. However, the emphasis on the different motives of particular individuals obviously changes as their "sports career" progress. For example, a newcomer at a multi-day cycling race retrospectively explains his motives; $\{w A\}$ explained that "Initially I started running just to get in shape, but one by one, and I became a regular weekend warrior. So now I am here." Another example, an experienced non-elite triathlete $\{\mathrm{wA}\}$ talks about the reasons for participating in his next iron distance: "The first time it was really a challenge. Then: to repeat, and run faster. Then I gave up this senseless idea... Now this is probably tourism, socialization, lifestyle ... But the race itself is still a test." Moreover, it is not only males who talk about challenge and excitement. In an interview, to the question: "Why ..." we received a comprehensive answer from a woman with a traditional gender identity, "For the same reason you do ..."

\section{Sport as Goal-Setting}

Let's sum up the sub-total. First, the factor of goal-setting is the essential importance for an ordinary amateur, as well as for an elite athlete. The modern system of open-participation events allows these ordinary amateurs to build their own "line-ups" of goals and their own "eligibility" criteria. However, the "career" guidelines of ordinary amateurs under this system differ from those of elite athletes. In distance running, the marathon is considered to be a significant peak for conquest. In the triathlon, a kind of participation "peak" is the "Iron" distance, where the marathon is only the final segment. For cycling, these are multi-day races. In general, the career "line" of an ordinary athlete does not look like "from the 'Fit for Labor and Defense' badge to the Olympic medal", but rather like from $5 \mathrm{~km}$ runs to marathons, Iron distance triathlons, and multi-day races. The process of career "growth" develops gradually, taking four to five years, or sometimes more. Regular participation usually begins with short 5-10 km distances. Then amateurs participate in half marathons. Over time, they try themselves in marathons, triathlons, and 
ultra- and multi-day races. Not everyone strives to reach the top of this "career", limiting themselves to a feasible level. We heard comments from athletes like $\{\mathrm{wA}\}$ : "I tried halfIron, but I can't pull up more now.", or $\{\mathrm{wA}\}$ : "From time to time I run half marathons, the rest is not my format.", and $\{\mathrm{wA}\}$ : "I believe that Iron is the reasonable limit. Ultradistances are no longer a sport, but a mockery." According to official results, there is another clear pattern: the longer the distance, the lower the number of female participants. For example, in triathlons, women are about $1 / 3$ of all participants at sprint distances (where an average finish time is $\sim 1.5$ hours), about $1 / 5$ at standards ( $\sim 3$ hours), and half ( $\sim 6$ hours), and only 1/10 at "Iron" ( $\sim 12$ hours). It seems that some commensurate goals are being chosen.

Secondly, we can talk about sports participation as a specific form of pleasure, as well as about the gradual formation of light addiction over the course of many years of racing and training. Endurance exercises, as well as risk and racing excitement during competition, induces a kind of endogenous "euphoria". Even having achieved the intended goals, this ordinary athlete does not quit a sporty lifestyle. The situation of participation becomes a routine turning into a habit.

Thirdly, regular participation of the same people in mass-sports events implies the emergence of new social groups. Based on common hobbies, the new networks and opportunities for socializing emerge. A key feature of these mass-events is that they are held on off-days, and there is open access to everyone without selection by skill. The substitute for the races is group and personal training. Note that "group membership" still implies an "admission ticket". There are entry fees and training fees. Moreover, the minimum and sufficient "condition for membership" is the race itself. A personal line in official results acts as a fixation of the race completion, that is, its independent confirmation.

The lifestyle of an ordinary amateur implies an involvement in competitive activity and the training process with varying degrees of regularity. Some amateurs can practice only one sport, such as running. In case of amateur triathletes, the competitive activity may involve participation in a wide range of cyclic endurance events. It is not only the triathlon, but primarily distance running, road cycling, open-water swimming, crosscountry skiing, etc. Another remarkable fact should be pointed out: not all amateurs participating in triathlons consider themselves as triathletes. Many define themselves as active leisure fans, or universal athletes, or as persons engaged in some other sports in the past, or specifically as cyclists, swimmers, runners, skiers, mountain bikers, etc. This is what allows us to generalize our observations. Considering the problem of motivation, we believe that we can talk about an ordinary athlete, that is, a 40 -year-old $(+/-10)$ runner, skier, cyclist, swimmer, or triathlete, as a certain ideal type.

The races play a central role in the planning of the training process. Some athletes may directly talk about preparing for something specific; $\{\mathrm{aW}\}$ said "It's raining outside, I wouldn't run just like that, but since a [month] later I will participate in the [race] ..." You can often hear this formula in the subjunctive mood, as when $\{\mathrm{wA}\}$ told us that "We need to apply for something serious [an 'Iron', a 'half', a marathon, at least an 'olympic distance'], something it will make sense to prepare for." These athletes usually 
select a significant race or a combination of races in a season. Then, they get ready by regular participation in trainings and less-important races. Net-time costs for sports in this case can be 3-10 hours per week. The everyday sports routine of amateurs is usually a combination of training and racing in certain types of competitions. As a rule, it has a pronounced seasonality. There is a typical participation schedule; running and cycling from spring to autumn, triathlon and swimming in summer, and cross-country skiing in winter (for Northern countries).

"Competition every weekend" is a regularity of racing, and is a characteristic case rather than a figure of speech. In terms of casual leisure, it is similar to the well-known formula "every Friday we meet at the bar". When describing their schedule, they may say, as $\{\mathrm{wA}\}$ does, that "Every week [something] is held around, I try to participate". The norm looks like 20-25 various races per year. Some really "bring the score" up to 50 events per year, and these are 30-50-years old adults who have usual, non-sport jobs. However, the "participation menu" is individual. Specific set of races depends on physical fitness and current plans. Prepared middle-pack runners are really capable of starting 10-15 km and even $21 \mathrm{~km}$ races every week. Beginners are advised to "mature" for a half marathon for a couple of seasons of regular participation.

The foregoing supplements the thesis about the sports game as an effective way to engage in physical activity and as a means of forming a healthy lifestyle, while challenging the efficacy of an abstract "care for fitness". Let's turn to the second part which contains the most valuable details of observations, and where we emphasize the difference between the ideal motives and the real attitudes of non-elite athletes.

\section{Latent Motivation and Strata: Ordinary, Adequate, and Crazy}

Ambivalence is the most interesting phenomenon of field observations. We believe that the space of an ordinary participant's inner emotions is more complicated than a simple reduction to fit, fun, challenge, and socialization. It is necessary to talk about several, often contradictory, motives acting simultaneously and with varying degrees of intensity. We single out two of them, pointing to the key contradiction. The main set, which characterizes the practice core, is the motives of socialization, challenge, passing, extreme excitements, entertainment, etc. Another latent motive is traditionally mentioned, the superiority over the opponent, that is, "to win" "to be ahead", the situation of ranking in the race and according to its results, "the problem of losing".

This duality is perfectly reflected in the essay by Gennady Shvets, a sports journalist and writer, a sub-elite athlete in his youth, and a Russian Olympic Committee spokesman in the 200os. Inspired by distance running in the 1980 os (at the same time and the same age as Murakami), this Russian journalist actively shared with Soviet readers his experiences of conquering marathons, triathlons and multi-day races. Shvets wrote that "Even the girls overtook me ... the figure of the penultimate runner flashes ahead... he is not an athlete at all and has never really been, unlike me. I can feel how the half-forgotten fighting chromosome begins to move inside me: I should finish at least before the last 
one. No, I shouldn't, just the last. Be the last one, but be alive" (2008). The same duality is seen in the case of the "elite-veteran" Shakhmatov. In the process of running, he "began to abstract and forget ... where and why I was in a hurry", seeing at the same time "that all the rivals around ... roll their eyes back from fatigue and take a step ... I understood that they were worse off; it "warmed me up", and I imperceptibly added speed" (1993).

The contradiction between the motives combined with the final ranking forms three conditional strata inside the practice. These are Ordinary, Adequate, and Crazy athletes (not counting the Elite stratum). These strata can be identified by participant observation as well as during interviews, according to reaction to the questions: "How important is your ranking place to you?", and "People say that the main goal is just the finish line, but is that so?" It is important to clarify that the practice of mass-participation races entails the publication of official results indicating times and places for all athletes. Moreover, the ranking is done not only in absolute male and female categories, but usually also in sex-age groups with 5-year increments (M/F 16-19, 20-24, 25-29, 30-34, 35-39, 40$44, \ldots 80-84,85-89$, etc.). That is, it is often done with the award ceremony for the first three places in each category.

\section{Motives, ranking, strata}

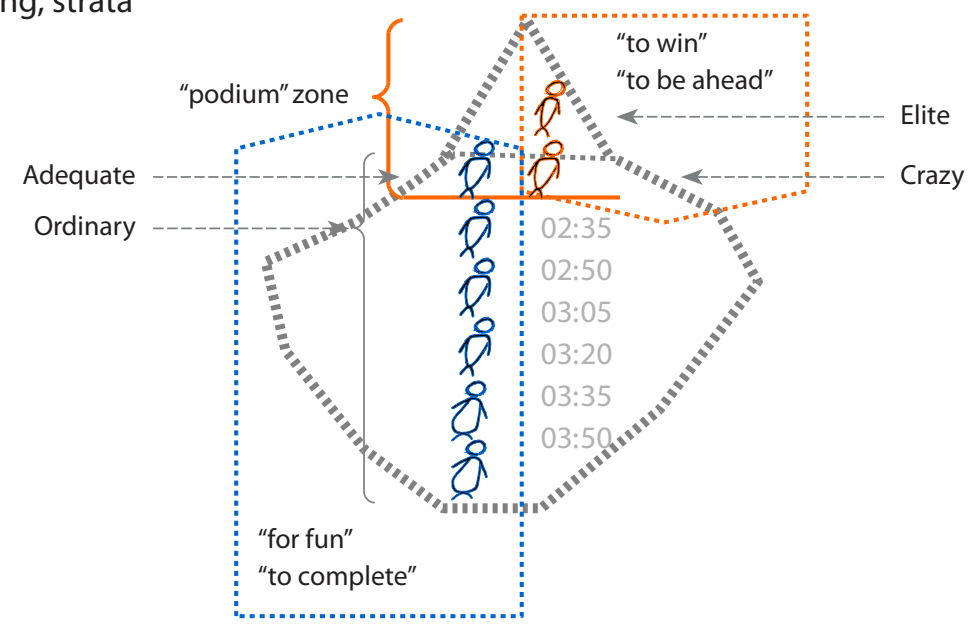

The "Ordinary" (mid-packers, averages, or mid-levels) are non-elite amateurs who regularly take part in mass-participation events, but do not win the races even in their own age-groups, and calmly accept the "fact of losing". They constitute the bulk of participants, or the core of the practice (they are the Runners in Smith's and Thompson's terms). They perceive the competitive process as a means of entertainment, regardless of its results. The very fact of participation has its own value, along with fit, fun, challenge, and socialization. During permanent participation in races, the "ordinary" regularly intersect with specific persons, perceiving them as rivals. Meanwhile, the rival for them is rather the fellow who helps them to reveal their potential in full. The results of rivalry do 
not really matter for the status within the group. For instance, $\{$ wA $\}$ says that "Abilities are different, opportunities are different, age is different, how can we compare?"; another $\{w A\}$ realizes that "Three hundredth, five hundredth, you are not the first anyway.", and still another $\{\mathrm{wA}\}$ responds that "After the U-turn, the leaders are running towards me. I think: wow, how fast? But when I turn around, there is an even bigger crowd behind."

Formally, the "bottom" (in terms of speed) section of participants consists of two categories. There are the beginners who may be worried about their lack of skill, and the experienced people (most of them) who do not demonstrate such anxieties. Usually an explanation for their modest results is obvious, being age or some injuries. For example, a $\{w A\}$ says "Twenty years ago I was much faster, but circumstances did not allow me to do it. Now I just want to put a tick."; another $\{$ wA $\}$ explains that "I'm already competing with myself", while $\{\mathrm{wA}\}$ says that "Others are lying on the couch, while I'm still moving." Those for whom this race format is their current limit of possibilities do not express their feelings about losing. Tears and a genuine expression of joy (the subject does not realize that he/she is being watched) are all easy to see in the final kilometers of long distances, especially in the triathlon. Similar experiences were noted by other observers, such as "I'm going to get in there. For me. I'm just about dead last. No one is watching me. No one cares. But I'm gonna do it for me" (Taormina 2010).

Symbolic status (if one can speak of it within the ordinary community) is determined through the participation experience and its duration. When meeting new people, they are more likely to be interested in "Did you participate in [something specific]?", "Where have you been, what's interesting there?" and "Who are you?". The question of "What is your time?" is asked, but is not the first question.

The "Crazy" (or "Obsessed", "eternal sub-elite", "over-amateurs", "bruised by podium", “jocks", “elite underachievers”, "water-pumping-station's champs”, etc.) are non-elite amateurs who periodically win competitions in their relevant age-groups and show prestigious results, while directly or indirectly declaring their motives (victory, podium, top-results, etc.). It will not be superfluous to note that these are athletically talented people, well-trained, and often with a background in sub- or elite sports. This is reflected in a $\{w A\}$ 's answer that "These are the athletes aka "Wanna be's", "I want to be the best". They have the motivation, dedication, cool equipment ... they look fast. But they just don't have the natural talent to be the best! They are the "obsessed" athletes ... who train hard, want to win, but end up finishing in the middle of the field [if in the elite category]. They are the ones hanging around the elite trying to fit in, showing off their cool gear but ultimately aren't in the fastest group."

At the same time, the "Crazies" treat the "Ordinary" ones with some arrogance, considering the value of sport as participation to be the invention of those "offended by podium"; a $\{$ wA $\}$ reflects that "Yes, I know all this: just a finish, blah blah blah. But I train hard; go to the goal, looking forward to success. Of course, it's easier for someone to say: just a finish." The size of this stratum is not very significant. Based on our observations, it can be estimated as $7 \%$ for a typical, large Western triathlon. The notable exception will be Ironman Hawaii, the WTC World Championship. "If you take a typical triathlon, then 
everything will be exactly like this: $90 \%$ just want to have a good time, just a finish," says one of the experts we interviewed (the director of large mass-competitions), and continues to say that "But there is only one start where the situation is reversed, the Ironman Hawaii." Ironically, this race, which at the dawn of the triathlon gave birth to the very "ethos" of a long distance, today has become a counter-example. The selective application principle turns the non-elite amateur triathletes attending this event into de-facto professionals.

The latent antipathy of these strata is quite obvious. For example, the attitude of the "Ordinary" towards the subculture of qualification for the Ironman Hawaii is rather negative. A $\{\mathrm{wA}\}$ says that "Qualifying for Ironman Championship, training 20 hours a week, etc. - these guys make me a little nauseous. Adventure racing has a healthier environment"; another $\{\mathrm{wA}\}$ states that "There are crazy people who are focused on their results, training, nutrition, sport plans. These themes are imposed on others. They turn a simple group trip into a competition. But you should ignore such people and enjoy your day", while another $\{\mathrm{wA}\}$ responds that "Yes, I'm not cool, I haven't been to Hawaii, I didn't even try. Yes, maybe I'm just for finish. But I have a good job, enough time for my family, unlike many cool ones." A similar opinion is expressed by writer Martin Dugard when he writes that "The "cult of me" that permeates Kona during Ironman week ... To say that it was more than a little off-putting would be an understatement." He noted: "I know that there are Ironman triathletes out there who balance work, family and training. [But] I haven't met any of them... I love the sport, but the culture surrounding it makes me squeamish ... I can't see myself training 20-30 hours a week" (2008). Albeit unintentionally, we were lucky enough to see something like this. In 2019, we were looking for respondents at the Ironman 70.3 World Championship on the eve of event, which is just the second and the last WTC race, which is not open to all and is based on the selection among non-elite triathletes. There was an unexpected result; women actively agreed to be interviewed, but a number of men refused because of their busy schedule (sic). Moreover, ordinary "non-selective" triathletes in this region were as sociable as in others. Ordinary athletes usually enter into dialogs willingly, leave their contact information in case of new questions, and the bounce rate is close to zero.

Triathletes \& Time for sports

(hours per week)

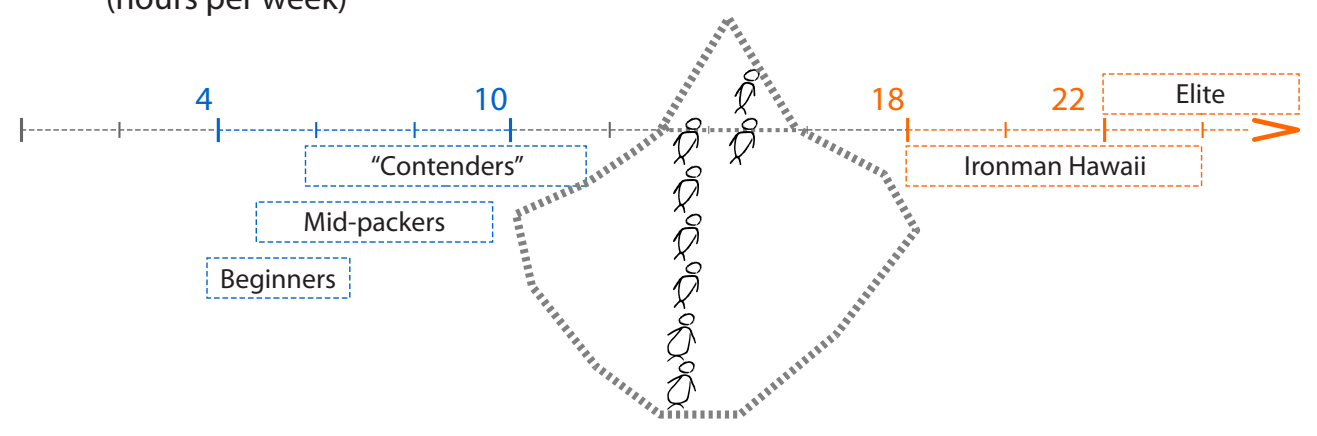


The antipathy of strata can be identified through participatory observation and group discussions, for example, during a long climb on a stage of a multi-day cycling race among a small group of riders who didn't know each other before the race. These are mainly men in a middle of the peloton, far away from the podium zone. The conversation begins with a discussion about uniforms because two riders wear jerseys of triathlon clubs. Then, it turns out that almost all of the group members have the experience of a triathlon. A lively exchange of impressions begins, as in who participated, where the competition was held, how it was there, etc. The only female in the group (claiming a podium in her category) says she was selected for Hawaii twice. All suddenly fall silent, showing a reluctance to continue the chatter. Silence hangs in the air. After a pause, the female starts making excuses; "If you are a girl, it's easy to do, especially in my group. I have time to train, I work as a coach. I have a daughter." The group answers her that "Ok, great. You are cool, we are losers!" [with a smile], and "Don't quarrel, let's talk about soccer?" The conversation continued, but on a different theme.

The "Adequate" are those non-elite amateurs who also occasionally hit the podium in their age categories and show prestigious results, although they share the opinions and values of the "ordinary" group in the context of conversations. They describe the podium's proximity as a danger rather than as a desired happiness. Comments range from a $\{\mathrm{wA}\}$ saying "This thought — won, lost — must be driven out as far as possible.", while another $\{\mathrm{wA}\}$ opines that "It's clear that you can insist, start training and get everyone out ... but what's the point? They'll give you plastic bullshit, and that's all." The expression "to be driven out" can be explained as recognition of the symbolic status of a "champion". Moreover, this status does not have a high value within the community itself, and is very expensive in terms of time-costs. Rather, it has an external value (for those persons who are not involved in the practice, and to the beginners who have not yet understood it).

Unethical behavior is clearly associated with the symbolic status of a "champion" and is characteristic of highly-trained amateurs. The number of anonymous confessions of doping is twice as high among the participants of the Ironman triathlon in Frankfurt (19.8\%) than among similar races in Regensburg (10.3\%) and Wiesbaden (9.7\%) (Dietz et al., 2013). The obvious reason is its status. The Frankfurt race is positioned by the WTC as the European Ironman Championship. There are some other forms of fraud, such as distance shortening, external "aerodynamic assistance" during cycling (where drafting is banned), as well as technical doping (mini-electric motors that give a small, but significant increase in power for victory). It is important to emphasize that these facts are rare. They are difficult to control in mass-races among non-elite amateurs.

\section{The Specifics of Russian Observations}

Domestic materials of Russian participant observations are more vivid for describing the latent antagonism of strata. Unlike in the West, the Russian fitness boom in the 199 os passed through a severe recession for economic reasons. The non-elite segment was accordingly smaller. The tradition of awarding by age-groups, combined with small 
numbers of participants, created the "permanent winners" and shaped the "Crazies" as a counterculture in a whole non-elite adult segment (so called masters or veterans). If not taking distance running and triathlon into account, it was typical for Russian veteran sports in the 2ooos. Non-elite events are often organized around the Top-achievements or Traditional-competitive model of sport in the spirit of the Olympic Games. This discourages "Ordinary" sportsmen from further participation. There are many examples. We recorded $\{\mathrm{sA}\}$ saying "When I finished among the last ones, I heard: "We have to get rid of people like these". To be honest, it hurts a lot."; from $\{\mathrm{XC}$-cycling\}: “They overtake us in a lap with shouts: "Get out, get away." It was very unpleasant, you feel superfluous."; from \{Road cycling\}: "We were only a couple of minutes behind the group, but the finish line was already closed for us. Why participate at all if we are not considered as humans?"; from \{Road cycling\}: "The feeling is that all this is for those who fight for prizes - but we ourselves are superfluous, for a makeweight, to collect money on fees. Why do participate again?”; from \{Nordic skiing\}: “The race on March 8, Women's Day. Lip service: “Gifts for all women." In practice: The organizers don't care about last participants, no any solemnity or attention; "a gift" is an unattended box of mimosa flowers; like "take it yourself". It's a shame."; and from \{Swimming\}: "I was there once; I don't want to do it again. It looks as if they make you feel that you are a loser."

The "Adequate" ones, in turn, refer to the "Crazies" with a fair amount of irony. They treat them as people who cannot find the boundary between hobby and everyday life; they are seen as those who did not grow up, did not realize themselves in top-sports or even in life, and now are trying to realize their ambitions in mass-sports. It is the "Adequate" ones that speak most vividly and with many details about the "Crazies". Everything is done behind their backs, on the condition of anonymity. At the same time, the "Crazies" consider the "Adequate" ones as a part of their own group. Representatives of different domestic subcultures of veteran sports have similar statements, such as from \{Athletics\}: "I look at these people and think: What is it? Is this compensation for a failed career, for a small apartment, for a modest salary?"; from \{Swimming\}: "We have two groups. Some are party-goers and convivialists, others are elite underachievers. For the first group, the main thing is just to get together, to talk, and to drink. The latter ones went crazy about medals and sport achievements. Once they did not succeed in top sports, now they compensate for it at "water-pumping stations' championships". That's what they're living for."; from \{Swimming\}: "Look, they write: "So-and-so made a gift to his club. He won two medals at international competitions ..." Well, what a gift? It was an ordinary small-town event, but they talk about it as if it were the Olympics."; from \{Athletics\}: At Masters European Championships: "It was very funny to look at our Russians masters. Especially those who are not yet veterans by age, and have not been realized in top-sport . . . But nevertheless, their ambitions, the seriousness of their training, this is "to win", their demeanor! And at the same time there are foreigners, Finns, Swedes, who are much more relaxed. Of course, I don't tell them all these things to their faces, because you can ruin the relationship"; and from \{Athletics\}: "I would like the principle to be: 'If you come yourself, then bring a comrade. But our veterans are different. They think: 
'I will bring a friend, and he suddenly wins. And what then? Am I not a champion any longer?"”

It is easy to hear the discussion of the "Crazies" by the "Adequates" outside the initiated dialog, just during a simple observation. For instance, from \{Waterpolo\}: "Listen, this Namesake is so cool! He doesn't know how to lose at all! He argues with the referee, and grabs the opponent's asses under water, and the team does not suit him, and the players are not well distributed. He's so funny, why don't we let him come more often?", and from \{Soccer\}: "The contrast [at the veteran tournament] is striking: our Russians are staking all. While Italians and Germans are considerably more relaxed: they came for fun, everything is fine for them, sincere smiles on their faces. Although their playing skills are the same." Some notes of the "Adequate" ones are induced by the contrast between two or more practices in which they are involved. We recorded responses from \{Swimming\}: "In my age group I am constantly on the podium, but there are almost no one of those who take 4th-5th-6th places and below. They come, but almost do not remain. It's amazing to be compared to triathlon and running", and from \{Road cycling\}: "It's a pity that I got injured and can't run anymore. There is a much healthier atmosphere on the runs than in veteran's cycling. People are nicer, less show-off."

Another one observation from the 2000 s is that both strata, the "Crazies" and the "Adequates", are severely critical when active elite athletes (usually from the "2nd division") apply to non-elite categories. They consider this practice to be utterly unethical, since sport is a source of income for the elite, while it is a leisure hobby for veterans.

The subculture serves as a carrier for external social norms, provoking or adapting individual behavior. For example, $\{\mathrm{sA}\}$ says that "If I would have swum $1.5 \mathrm{~km}$ in 20 minutes, I probably would not have found a triathlon for myself. But with my modest speed, I didn't fit into their swim-gang.", while \{Swimming\} states that "Now you need to go 200 meters faster than in 2 minutes to show something. This is awful, a lot of time has to be spent; probably, they are all doped. [And what then, do you want to do all this?] I don't, but it's uncomfortable to be superfluous, I would like to look decent." The rigidity of the previously-learned social norm is noteworthy when the environment changes. The second wave of the fitness boom has been actively rising in Russia for the last fifteen years. Accordingly, since 2012, a trend has emerged to provide paid services for a growing audience of non-elite amateurs by ex-, sub-, and elite athletes. It is interesting that Elite and "Crazy" sportsmen who are actively involved in the providing of coaching services for the "Ordinary" ones remain the carriers of the Top-achievements norm. The hidden arrogance is quite obvious here; $\mathrm{a}\{\mathrm{sA}\}$ notes that "I am looking [at the client]: everything looks aesthetically awful; all the same, nothing really will turn out, well, it's stupid, he is just wasting time", while $\{\mathrm{sA}\}$ says that "They call their clients behind their backs the bonnets. [Why?] Because clients are boobies, teapots, dummies." Another $\{\mathrm{sA}\}$ explains that "We are training loaves now. [What?] Well, age-groupers, amateurs", and another $\{\mathrm{sA}\}$ notices that "I am surprised: coaches earn their living on it, they must be customerfriendly. But they work as if their client is despised, and it's being felt. Like, "why do you need this, you don't show anything anyway"'. 


\section{Discussing the Above}

We believe that the best interpretation of the described phenomena can be given if it is based on the thesis of the evolutionary origin of social behavior in combination with the civilizational approach of Norbert Elias. It presupposes behavioral modification through the transformation of socio-cultural norms. Let's return to our two sport models, the Expressive (where the goal is to enjoy the sports game itself), and the Top-achievements (where the goal is to win, to be ahead, to set a record, etc.). These two models of sport, in our opinion, imply two sets of logic of its understanding, the Intuitive and the Reflexive. The Intuitive is simpler and operates in terms of "win-or-lose", "follow the leader", or "friend-or-foe". This intuitive logic from the standpoint of biology and evolutionary anthropology is nothing more than an innate behavioral program. It is characteristic of Homo sapiens, our ancestors, and present-day distant relatives. Friend-or-foe identification and solidarity with one's own fellows, the process of ranking, and following the leader are all important elements of animal social behavior, including humans. The rank allows to instantly build a hierarchy of subordination, and to start joint actions without a long process of deliberation. The so-called management pyramid, the hierarchy, is not at all the achievement of present-day effective managers. It is just the innate heritage of evolutionary process, that is, an intuitive knowledge.

The "pyramid" metaphor, an often-cited representation of social order in sports, is outlined by Pierre de Coubertin in the six lines passage of the note of a page-and-a-half length, where he wrote "For one hundred to be engaged in physical culture, fifty must be engaged in sport ... twenty must specialize ... five must be capable of amazing feats." The argument takes only one line: "Any serious practitioner knows and feels this" (1913). ${ }^{2}$ We believe that Coubertin's insight comes from intuitive knowledge, and appeals to it. Regarding the necessity of sports, we believe that everything is correct. Rivalry creates the goal for meaningless activity; it is a means of extreme efforts at the individual level. As a result, it produces positive effects. However, the "naturalness" of a "pyramid" does not mean its perfection. The problems are the lack of growth inside the hierarchy and a fixed unambiguous ranking. Sport, unfortunately, generates such a fixed ranking due to the biological inequality of abilities. The position of the upper classes in the community is honorable and pleasant, the middle level is acceptable to the majority, and the position of the lower layers is dishonorable and unpleasant. We believe that an important humanist task is the breaking of an unambiguous ranking through its reassessment. We need a society without the bottom, a society consisting of many subgroups, and a situation where an individual simultaneously belongs to different hierarchies at different statuses.

"Athlete, spectator, does it really matter ..."; these roles are mixed for Pierre Bourdieu, who raises the question of acquiring a taste for sports (1993). However, in our case, these roles collide. Umberto Eco uses the allegory of sports and sports beyond the line, opposing them to each other. His sports is an amateur one that a person does for himself (sport-as-participation). Sport below the line is an elite (professional) sport that is gener-

2. The original in French: "N'importe quel praticien sérieux sait et sent cela." 
ated by sport squared: "others play, I watch" (sport-as-spectacle) (1998). A similar thought was expressed by John Hobson, who quite subtly compared sports with the difference between military actions observed from a front-line trench and from the rear. He writes about the gradually emerging brotherhood among the belligerent soldiers and about the implacable jingoism of those in the rear (1902), (where the short meaning of jingoism is that the loudest call for war is usually heard from those who will never go to it).

Sport for the jingo-spectator is a game of victory for one's own fellows, an association with one's own players and, of course, a demand for victory. The ranking is unambiguous: it is friend or foe, or won or lost. Through self-assertion, when one's own fellows (who are their own "avatar") are winning, the viewer objectively feels better. Moreover, dictating the rules of a game on the field, the jingo-spectator crowds out the actual participant who wins nothing and is unattractive.

Sport for the player is an ultimate effort to fight an opponent, forces of nature, or circumstances. Ranking matters, but victory through a cultural imperative can be interpreted quite loosely, as your result, your achievement, victory over distance, and over yourself. As one of our respondents, $\{\mathrm{wA}\}$, said, "I can't do anything with my opponent, but I'll do my best!"

An expressive model of sports solves the "pyramid" problem and highlights the reflexive logic of its understanding. This logic is more complicated than the intuitive one and implies the following chain of reasoning. Rivalry as a means of extreme efforts $\rightarrow$ positive effects of extreme efforts $\rightarrow$ inequality of abilities in a social group $\rightarrow$ emerging ranking as a problem of crowding out losers $\rightarrow$ solution of the problem through the reevaluation of ranking in a new imperative (an external social norm). We believe that the very phenomenon of modern mass-participation sports emerged only due to the gradual recognition of the Expressive model as a new social norm. Thompson's view of "Why do these buggers run?" (1983) reflects his rejection of mass-sport from the standpoint of the old norm. We emphasize that what really matters is not the ranking after the game but the social assessment of its results. The imperative of challenge and its feasible criterion creates a goal for everyone. Through this imperative, the lower layers of hierarchy rise above those who are outside the practice. The ranking maxims within the group of those involved are thus pushed into the background. The situation is different in the case of the win-lose imperative: the challenge maxim is devalued. The sportsman is forced out into the stands or onto the coach's bench. The imperative of top-achievement is even more negative: in this case, the ranking acquires a universal, almost totalitarian character.

\section{In Conclusion: Practical Implications}

Let's return to the "pyramid" metaphor and the contradictions between the two segments of sport. We believe that an obstacle for the grassroots segment's development is not an elite sport by itself. Top-achievement sport is inevitable, since striving to be ahead of the others is inherent to human nature. The main problem is the application of the Topachievements norms of the elite level (the demands to win, to show the best result, or to 
set a record) to the grassroots level. As a consequence, the exclusion of a large number of ordinary sports participants takes place. The task of competition organizers, therefore, is to introduce an alternative social norm: the game convention of contests, indifference to results, the acceptability of losing, and the interpretation of "winning" outside the ranking. This allows us to build and maintain a subculture focused on formally-non-winning ordinary athletes that can be called an Expressive social norm for sports.

A similar model is implemented de facto within the mass-participation endurance competitions that exist today. Their organizers and the bulk of participants consider, first of all, the fact of completing the distance as an achievement, and the race itself as a challenge for the competitors. The motive of challenge and excitement (but not achieving a high result) is positioned and perceived as a normative ideal. Within this system of values, the rival is considered as rather a fellow; the in-game competition allows you to reveal yourself in full, to do your best. As a result, victory does not mean anything and the loser does not forfeit his status, since both rivals showed stamina and courage, and making every effort during the contest. Here we are talking of situational temporary rivalry in the conventions of a sports game.

The expressive model is realized through a number of rules, conventions, and rituals that are typical for such competitions today. In particular, these are an open-race entry without selection by skill or age, democratic time limits, the age-groups ranking separated from an elite one, and the tradition of giving everyone "care tokens" like commemorative medals and gifts, etc. All of this literally mixes up linear rankings. In particular, almost all 70-80-year-old sportsmen are usually honored as podium-winners (since there are so few of them), although they formally cross the finish line among the last. A successful tool is the unity of practice combined with the separation of two normative roles, those of the elite (professional) and the age-group (ordinary) sportsmen. It allows for the application of the norm of gaming conventions for the bulk of non-elite amateurs and to require high results only from the elite. The result is the domination of the Expressive model with which the Traditionally-competitive one can quite easily coexist within some clear framework.

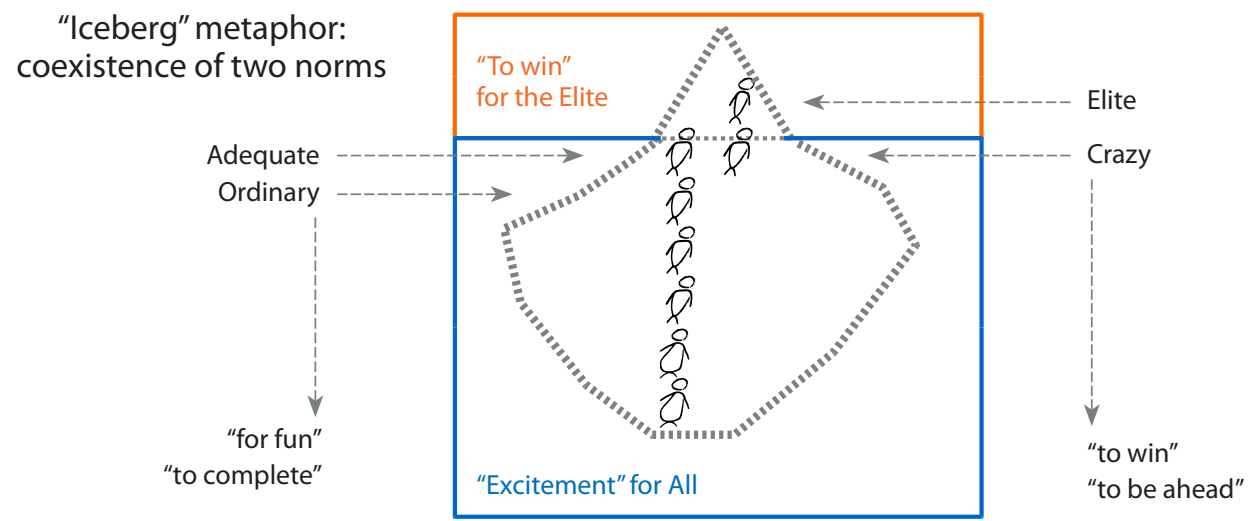


Summing up, instead of the "pyramid" metaphor for mass-sports, we suggest using the "iceberg" metaphor. Its managerial meaning is an allegory of a single body in two environments (models), where the normative role changes at their border. The phenomenon of the "Crazies" is a dropout from the prescribed ethics, which is characteristic of the boundary layer. Here we see the obvious "trickle-down effect" of elite sports. The opportunity to win the symbolic status of "champion" provokes a denial of gaming conventions. Payment for this will be the time that the "Crazy" sportsman has to spend; his behavior can become a counter-example. However, the phenomenon itself is inevitable. This leads to the idea of futile attempts to find some "pure amateur sport", somehow delineating it from the elite (or professional) one in terms of different competition systems. Cutting off the above-water "iceberg" part, we will only force it to bring a new "pyramid" to the surface. However, we agree with the opinion expressed earlier: the metaphor of the "sport pyramid" is dysfunctional, and that the time has come for it to recede into the past.

\section{References}

Adelfinsky A. (2013) Piramida ili aysberg? O razlichnykh modelyakh sporta i ikh ekonomicheskiye posledstviyakh [A Pyramid or an Iceberg? Various Sports Models and their Economic Implications]. Logos, no 5, pp. 139-158. (In Russian)

Adelfinsky A. (2018) Nazlo rekordam: opyt issledovanija massovogo sporta [Despite the Records: An Inquiry into Mass Participation Sports], Moscow: Delo. (In Russian)

Adelfinsky A. (2020). Creating a Hero ... Laughing at Clowns? Representations of Sports and Fitness in Soviet Fiction Films after the Olympic U-Turn in Politics. Russian Sociological Review, vol. 19, no 4, pp. 108-136.

Andreff W., Dutoya J., Montel J. (2009) Le modèle européen de financement du sport: quels risques? Revue Juridique et Economique du Sport, pp. 75-85.

Andryushina L. (2016) Sravnitel'naya antropologiya Konrada Lorentsa: metodologicheskiye strategii [Comparative Anthropology of Konrad Lorenz: Methodological Strategies] (PhD Dissertation). Kursk. (In Russian)

Atkinson M. (2008) Triathlon, Suffering and Exciting Significance, Leisure Studies, vol. 27, no 2, pp. 165-180.

Bourdieu P. (1993) How Can One be a Sports Fan? Cultural Studies: A Reader (ed. S. During), London: Routledge, pp. 339-360.

Case R., Branch J. D. (2001) Event Marketing: An Examination of Selected Demographic and Psychographic Data of Participants Competing in the World's Foremost OffRoad Triathlon Event. International Sports Journal, vol. 5, no 1, pp. 118-127.

Castellanos-García P., Kokolakakis T., Shibli S., Downward P., Bingham J. (2021) Membership of English Sport Clubs: A Dynamic Panel Data Analysis of the Trickle-Down Effect. International Journal of Sport Policy and Politics, vol. 13, no 1, pp. 105-122.

Coubertin P. (1913) Une campagne contre l'athlète spécialisé. Revue Olympique, no 91, p. 114 . 
De Bosscher V., Sotiriadou P., Van Bottenburg M. (2013) Scrutinizing the Sport Pyramid Metaphor: An Examination of the Relationship between Elite Success and Mass Participation in Flanders. International Journal of Sport Policy, vol. 5, no 3, pp. 319-339.

De Cocq S., De Bosscher V., Derom I., De Rycke J. (2018) Elite Sport and Sport for All: An Epistemological Paradox. Managing Sport in a Changing Europe: Book of Abstracts, European Association for Sport Management, pp. 283-284.

De Rycke J., De Bosscher V., Funahashi H. (2021) The Cure or the Cause? Public Opinions of Elite Sports' Societal Benefits and Harms. Sport in Society, vol. 24, no 7, pp. 10701092.

Dietz P., Ulrich R., Dalaker R., Striegel H., Franke A. G., Lieb K., Simon P. (2013) Associations between Physical and Cognitive Doping: A Cross-Sectional Study in 2.997 Triathletes. PLoS One, vol. 8, no 11, art. e78702.

Dugard M. (2008) Iron Week. Available at: http://www.martindugard.com/blog/20o8/10/ iron-week.html (accessed 25 November 2008).

Eco U. (1998) Faith in Fakes: Travels in Hyperreality, London: Vintage.

Elias N., Dunning E. (1986) Quest for Excitement: Sport and Leisure in the Civilizing Process, Oxford: Blackwell.

Getz D., McConnell A. (2010) Serious Sport Tourism and Event Travel Careers. Journal of Sport Management, vol. 25, no 4, pp. 326-338.

Gleyse J., Jorand D., Garcia C. (2001) Mystique de "gauche" et mystique de "droite" en pédagogie sportive en France sous la Troisième république. Stadion, no 27, pp. 125-137.

Grix J., Carmichael F. (2012) Why do Governments Invest in Elite Sport? A Polemic. International Journal of Sport Policy and Politics, vol. 4, no 1, pp. 73-90.

Heinemann K. (1998) Einführung in die Soziologie des Sports, Schorndorf: Hofmann.

Hindley D. (2020) "More Than Just a Run in the Park": An Exploration of Parkrun as a Shared Leisure Space. Leisure Sciences, vol. 42, no 1, pp. 85-105.

Hobson J.A. (1902) Imperialism: A Study, New York: Pott \& Co.

Kirkeby M. (2007) The Pyramid Sport Model: A False Representation of Reality. Available at: http://www.isca-web.org/english/library/articles/thepyramidsportmodel (accessed 15 June 2021).

Kirkeby M. (2009) The Pyramid is History! The Real Challenges and Conflicts between Grass-Roots and Top Sport. Available at: https://www.playthegame.org/uploads/media/Mogens_Kirkeby_-_The_pyramid_is_history.pdf (accessed 15 June 2021).

Kondrashov A. (1995) Paradoksy triatlona [Paradoxes of Triathlon]. Fizkultura i sport, no 9, pp. 28-29. (In Russian)

Kruger M., Myburgh E., Saayman M. (2014) A Motivation-Based Typology of Triathletes. South African Journal for Research in Sport, Physical Education and Recreation, vol. 36, no 3, pp. 117-134.

Lamont M., Kennelly M. (2012) A Qualitative Exploration of Participant Motives Among Committed Amateur Triathletes. Leisure Sciences, vol. 34, no 3, pp. 236-255.

Makshanchikov K. (2020) Russians' Spending on Sports: Econometric Analysis on Levada-Center Data. Applied Econometrics, vol. 6o, pp. 115-138. 
Manzhosov V. (1986) Lyzhi - v byt naroda! [Skiing — to Everyday Life of the People!]. Lyzhny sport, no 2, pp. 3-6. (In Russian)

Matveyev L. (1999) Sport dlya vsekh i sport ne dlya vsekh [Sport for All and Sport not for All]. Sport for All, no 1-2, p. 15. (In Russian)

Medvedev D. (2008) Nashi sportsmeny pokazhut sebya na Olimpiade! [Our Athletes will Show Themselves at the Olympics!]. Komsomolskaya pravda, May 22. (In Russian)

Murakami H. (2008) What I Talk about When I Talk about Running, New York: Alfred A. Knopf.

Nikolaidis P. T., Heller J., Knechtle B. (2017) The Russians are the Fastest in Marathon Cross-Country Skiing: The "Engadin Ski Marathon". BioMed Research International, vol. 2017, art. 9821757. Available at: https://www.hindawi.com/journals/ bmri/2017/9821757/ (accessed 15 June 2021).

Ogles B. M., Masters K. S. (2003) A Typology of Marathon Runners Based on Cluster Analysis of Motivations. Journal of Sport Behavior, vol. 26, no 1, pp. 69-85.

Payne W., Reynolds M., Brown S., Fleming A. (2003) Sports Role Models and Their Impact on Participation in Physical Activity: A Literature Review, School of Human Movement and Sport Sciences, University of Ballarat.

Petrunin Y., Chataeva O., Bagatirova A. (2016) Kak mozhno byt' futbol'noy bolel'shchitsey? [How to Be a Female Football Fan?]. Public Administration, no 54, pp. 5-38. (In Russian)

Poczta J., Malchrowicz-Mośko E. (2020) Mass Triathlon Participation as a Human Need to Set the Goals and Cross the Borders: How to Understand the Triathlete? Olimpianos: Journal of Olympic Studies, no 4, pp. 244-254.

Roshchina Y., Gremchenko E. (2016) Faktory sklonnosti k zdorovomu obrazu zhizni. [Factors of Propensity to a Healthy Lifestyle]. RLMS-HSE Bulletin, Issue 6, Moscow: HSE, pp. 118-163. (In Russian)

Seguí-Urbaneja J., Inglés E., Alcaraz S., De Bosscher V. (2020) Sport Pyramid Metaphor: Trickle Down and Up Effect in Spain. Revista Internacional de Medicina y Ciencias de la Actividad Física y el Deporte, vol. 77, no 20, pp. 1-20.

Semashko H.A. (1927) Desyat' let sovetskoy fizkul'tury [Ten Years of Soviet Physical Education]. Teoriya i praktika fizicheskoy kultury, no 5, pp. 5-9. (In Russian)

Shakhmatov A. (1994) Triatlon - pervaya popytka [Triathlon, the First Attempt], Moscow: Prize. (In Russian)

Shipway R., Holloway I., Jones I. (2013) Organisations, Practices, Actors, and Events: Exploring Inside the Distance Running Social World. International Review for the Sociology of Sport, vol. 48, no 3, pp. 259-276.

Shvets G. (2008) Sneg v Sakhare [Snow in the Sahara]. Russky pioner, no 2. (In Russian) Sleamaker R., Browning R. (1996) Serious Training for Endurance Athletes, Leeds: Human Kinetics

Smith S. L. (1994) Reclaiming Masculinity: A Sociological Study of Running Repairs (Ph.D. Dissertation), University of Leicester. 
Smith S. L. (1998) Athletes, Runners, and Joggers: Participant-Group Dynamics in a Sport of “Individuals". Sociology of Sport Journal, vol. 15, no 2, pp. 174-192.

Smith S. L. (2000) British Nonelite Road Running and Masculinity: A Case of "Running Repairs"? Men and Masculinities, vol. 3, no 2, pp. 187-208.

Stolyarov V. (2019) The Failure of the Humanistic Mission of Olympism and Humanistic Sport Movement as a Global Problem of the Modern World. Vek globalisatii, no 2, pp. 97-110.

Taormina S. (2010) Top Tri Talk 2009. Available at: https://www.slowtwitch.com/Features/Top_Tri_Talk_2009_1158.html (accessed 15 June 2021).

Thompson H. S. (1983) The Curse of Lono, Toronto: Bantam Books.

Uglov F. (2001) Cheloveku malo veka [Man is not a Century Old], Moscow, Science. (In Russian)

Van Bottenburg M., Scheerder J., Hover P. (2010) Don't Miss the Next Boat: Europe's Opportunities and Challenges in the Second Wave of Running. New Studies in Athletics, vol. 25, no 3, pp.125-143.

Vlasov Y. (1988) Zachem nam nuzhen sport? [Why do We Need Sports?]. Sovetskaya kultura, April 23, p. 8. (In Russian)

Weed M., Coren E., Coren E., Fiore eta. (2015) The Olympic Games and Raising Sport Participation: A Systematic Review of Evidence and an Interrogation of Policy for a Demonstration Effect. European Sport Management Quarterly, vol. 15, no 2, pp. 195226.

Zasimova L., Loktev D. (2016) Zanyatiya sportom - udel bogatykh? (Empiricheskiy analiz zanyatiy sportom v Rossii) [Sports for the Rich? (Empirical Investigation of Participation in Sport in Russia)]. HSE Economic Journal, vol. 20, no 3, pp. 471-499. (In Russian)

Zhukov D. (2013) Stoi, kto vedet? Biologiyapovedeni-ya cheloveka i drugikh zverei [Stop! Who's Ruling? The Biology of Humans' and Other Animals' Behavior], Moscow: Alpina Non-Fiction. (In Russian)

Zibunovskaya N., Pokida A. (2011) Svobodnoye vremya i dosug kak usloviya formirovaniya zdorovogo obraza zhizni rossiyskogo naseleniya [Spare Time and Leisure as a Conditions of Russian Population's Healthy Life-Style Development]. Izvestiya of Saratov University. Series "Sociology. Politology", vol. 11, no 2, pp. 37-41. (In Russian) 


\title{
Ординарные, адекватные, недобегавшие: пересматривая метафору «пирамиды» для массовых видов спорта
}

\author{
Андрей Адельфинский \\ Кандидат экономических наук, доцент, Московский государственный технический университет \\ имени Н. Э. Баумана \\ Адрес: 2-я Бауманская ул., д. 5, стр. 1, Москва, Российская Федерация 105005 \\ E-mail: adelfi@mail.ru
}

Статья критически экзаменует метафору «пирамиды» для феномена массового партиципаторного спорта. В фокусе исследования - неоднородность внутригрупповой структуры и мотивов среди взрослых не-элитных любителей, участников массовых стартов по дистанционному бегу, триатлону, вело- и лыжным марафонам, заплывам и пр. Эмпирическую основу исследования составили материалы сравнительного включённого наблюдения на российских и европейских массовых соревнованиях и полуформализованные интервью. Очерчены стиль жизни и характерные мотивы неэлитных атлетов. Большинство участвует ради вызова, ради развлечения, дабы быть в форме, ради общения и пр.; что определяется как ключевые мотивы. Утверждается, что соревнования играют важную роль для регулярных занятий спортом и для вовлечения в здоровый образ жизни. Мотив же ради здоровья является побочным. Отмечен латентный мотив: выиграть, опередить соперника, быть не последним и пр. Он составляет саму природу спортивной игры, но порождает проблему проигрыша, отталкивающую от участия. Показано, как уровень мастерства и баланс между ключевым и латентным мотивами формирует три страты среди не-элитных атлетов. Ординарные и адекватные атлеты признают значимым ключевые мотивы, а недобегавшие - латентный. Продемонстрированы скрытые антагонизмы между стратами. Теоретическая интерпретация основана на концепции цивилизационного процесса Норберта Элиаса и сравнительной антропологии Конрада Лоренца. Мы обсуждаем две нормативных модели спорта. Для экспрессивной модели ключевые мотивы (ради развлечения и др.) являются социально-одобряемыми. Но для рекордистской легитимен лишь латентный мотив выиграть. Мы полагаем, что феномен партиципаторного спорта сложился благодаря признанию экспрессивной модели как социальной нормы. А рекордистская модель препятствует развитию массового спорта. Отказываясь от метафоры «пирамиды» спорта, мы предлагаем метафору «айсберга», где модели сосуществуют через разные социальные роли.

Ключевые слова: цивилизационный процесс, массовый спорт, спорт для всех, бег, триатлон, велоспорт, социальные нормы, социология спорта, эффект просачивания, элитный спорт 